\title{
ASSESSMENT OF CLINICAL AND BIOCHEMICAL PARAMETERS OF ACUTE PANCREATITIS- A CROSS SECTIONAL STUDY
}

\author{
D. M. Patel ${ }^{1}$, Pavan D. Patel ${ }^{2}$, Shruti Nair ${ }^{3}$
}

${ }_{1}^{1}$ Associate Professor, Department of Medicine, Vedanta Institute of Medical Sciences, Palghar, Maharashtra, India.

${ }^{2}$ Resident, Department of Medicine, KIMS, Karad, Maharashtra, India.

3Tutor, Department of Physiology, KIMS, Karad, Maharashtra, India.

\begin{abstract}
\section{BACKGROUND}

Acute pancreatitis is a common disease with wide clinical variation and its incidence is increasing. The average mortality rate in severe acute pancreatitis approaches 2-10\%. Severe acute pancreatitis (SAP) develops in about $25 \%$ of patients with acute pancreatitis. According to the severity, acute pancreatitis is divided into mild acute pancreatitis (absence of organ failure and local or systemic complications), moderately severe acute pancreatitis (no organ failure or transient organ failure less than 48 hours with or without local complications) and severe acute pancreatitis (persistent organ failure of more than 48 hours that may involve one or multiple organs). The present study was conducted to assess the clinical presentation of acute pancreatitis and thereby assess the diagnosis as well.
\end{abstract}

\section{METHODS}

The present study was a cross sectional hospital-based study, carried out among 50 indoor cases of acute pancreatitis admitted under department of general medicine, in a tertiary healthcare teaching institute in Maharashtra, during the period February 2018 to April 2018.

\section{RESULTS}

Almost all patients (96\%) with PP presented with abdominal pain and lump in abdomen (92\%). 62\% had complaints of fever, $46 \%$ presented with nausea and vomiting. $40 \%$ cases complained of weight loss.

\section{CONCLUSIONS}

Early assessment of severity and intensive care management of acute pancreatitis is of paramount importance. Lab markers especially high values of lipase and other markers could be important prognostic markers for predicting morbidity and mortality in acute pancreatitis.

HOW TO CITE THIS ARTICLE: Patel DM, Patel PD, Nair S. Assessment of clinical and biochemical parameters of acute pancreatitisa cross sectional study. J. Evolution Med. Dent. Sci. 2019;8(13):962-964, DOI: 10.14260/jemds/2019/215

\section{BACKGROUND}

Acute pancreatitis is a common disease with wide clinical variation and its incidence is increasing. The average mortality rate in severe acute pancreatitis approaches $2-10$ $\%$.[1] Severe acute pancreatitis (SAP) develops in about 25\% of patients with acute pancreatitis. Severe acute pancreatitis is a two-phase systemic disease. The first phase is characterised by extensive pancreatic inflammation and/or necrosis and is followed by a systemic inflammatory response syndrome (SIRS) that may lead to multiple organ dysfunction syndrome (MODS) with in the first week. About $50 \%$ of deaths occur within the first week of the attack, mostly from MODS. The formation of infected pancreatic necrosis or fluid collection occurs usually in the second week. The factors which cause death in most patients with acute pancreatitis seem to be related specifically to multiple organ dysfunction syndrome and these deaths account for $40-60 \%$ of inhospital deaths in all age groups. The mortality figures

'Financial or Other Competing Interest': None.

Submission 31-12-2018, Peer Review 13-03-2019,

Acceptance 20-03-2019, Published 01-04-2019.

Corresponding Author:

Dr. D. M. Patel,

Department of Medicine,

Vedanta Institute of Medical Sciences,

Palghar-401102, Maharashtra, India.

E-mail: researchexpert3@gmail.com

DOI: $10.14260 /$ jemds $/ 2019 / 215$

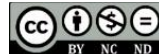

associated with MODS vary between $30-100 \%$. Infection is not a feature of the early phase. Pro inflammatory cytokines contribute to respiratory, renal, and hepatic failure. The "second or late phase" which starts 14 days after the onset of the disease, is marked by infection of the gland, necrosis and systemic complications causing a significant increase in mortality. The association between increasing age and death from acute pancreatitis is well documented. Respiratory failure is the most common type of organ failure in acute pancreatitis.[2]

According to the severity, acute pancreatitis is divided into mild acute pancreatitis (Absence of organ failure and local or systemic complications, moderately severe acute pancreatitis (No organ failure or transient organ failure less than 48 hours with or without local complications) and severe acute pancreatitis (Persistent organ failure more than 48 hours that may involve one or multiple organs). [3]

The present study was conducted to study the clinical presentation of acute pancreatitis among the suspected cases admitted to department of general medicine in tertiary case institute.

\section{METHODS}

The present study was a cross sectional study hospital based carried out among 50 indoor cases of acute pancreatitis admitted under department of general medicine in a tertiary healthcare teaching institute in Maharashtra during February 2018 to April 2018. 


\section{Source of Data}

All the cases of suspected acute pancreatitis admitted under department of general medicine in a tertiary healthcare institute, and fulfils the set inclusion criteria, who consented to participate in the study were included in the present study.

\section{Method of Data Collection}

The data was collected from cases fulfilling inclusion criteria using pre-designed, semi-structured, pre-validated proforma, in which history, clinical findings, investigation reports, were incorporated. Cases of ac ute pancreatitis were evaluated with detailed history, clinical signs and symptoms, the duration and investigations. Blood and urine investigations, Ultrasonography (USG) Abdomen and/or Computerised Tomography.

\section{RESULTS}

When we classified the participants according to their age groups, we found that majority of participants belonged to 31 - 40 years of age group (42\%) followed by 21-30 years (22\%).

\begin{tabular}{|c|c|c|}
\hline $\begin{array}{c}\text { Age Group } \\
\text { (in Years) }\end{array}$ & $\begin{array}{c}\text { Number of } \\
\text { Participants }\end{array}$ & Percentage \\
\hline$\leq 20$ & 2 & $4 \%$ \\
\hline $21-30$ & 11 & $22 \%$ \\
\hline $31-40$ & 21 & $42 \%$ \\
\hline $41-50$ & 9 & $18 \%$ \\
\hline $51-60$ & 5 & $10 \%$ \\
\hline$\geq 61$ & 2 & 4 \\
\hline \multicolumn{3}{|c|}{ Total } \\
Table 1. Distribution of Participants According to \\
\hline
\end{tabular}

\begin{tabular}{|c|c|c|}
\hline Gender & Number of Participants & Percentage \\
\hline Males & 39 & $88 \%$ \\
\hline Females & 11 & $22 \%$ \\
\hline Table 2. Gender-Wise Distribution of Study Participants \\
\hline
\end{tabular}

Out of 32 study participants, $88 \%$ were males and $22 \%$ were females (Table 2). Here we observed that male participants outnumbered the female participants.

\begin{tabular}{|c|c|c|c|}
\hline \multicolumn{2}{|c|}{ Personal History } & Number of Participants & Percentage \\
\hline \multicolumn{2}{|c|}{ Alcoholism } & 27 & $54 \%$ \\
\hline \multicolumn{2}{|c|}{ Smoking } & 12 & $24 \%$ \\
\hline \multirow{2}{*}{ Diet } & Mixed & 35 & $70 \%$ \\
\hline & Vegetarian & 15 & $30 \%$ \\
\hline \multicolumn{4}{|c|}{$\begin{array}{c}\text { Table 3. Distribution of Participants According to Their } \\
\text { Personal History }\end{array}$} \\
\hline
\end{tabular}

In this study it was observed that $54 \%$ patients had a history of chronic alcoholism, $24 \%$ patients had history of smoking. It was found that $70 \%$ of study participants were having mixed pattern of diet, while $10 \quad 30 \%$ study participants were having strict vegetarian pattern of diet (Table 3).

\begin{tabular}{|c|c|c|}
\hline Clinical Features & Number of Participants & Percentage \\
\hline Pain Abdomen & 48 & $96 \%$ \\
\hline Rigidity & 46 & $92 \%$ \\
\hline Fever & 31 & $62 \%$ \\
\hline Nausea / Vomiting & 23 & $46 \%$ \\
\hline Weight Loss & 20 & $40 \%$ \\
\hline Table 4. Distribution of Participants According to Their \\
\multicolumn{2}{|c|}{ Clinical Presentations } \\
\hline
\end{tabular}

The clinical presentation of cases of acute pancreatitis observed as per the present study was as given in Table 5 . Almost all patients (96\%) with PP presented with abdominal pain and lump in abdomen (92\%). 62\% had complaints of fever, $46 \%$ presented with nausea and vomiting. $40 \%$ cases complained of weight loss. (Table 4).

\begin{tabular}{|c|c|c|}
\hline $\begin{array}{c}\text { General } \\
\text { Examination }\end{array}$ & $\begin{array}{c}\text { Number of } \\
\text { Participants }\end{array}$ & Percentage \\
\hline Febrile & 28 & $56 \%$ \\
\hline Raised RR & 20 & $40 \%$ \\
\hline Pallor & 18 & $36 \%$ \\
\hline Icterus & 12 & $24 \%$ \\
\hline Tenderness & 38 & $76 \%$ \\
\hline Hypertension & 16 & $32 \%$ \\
\hline
\end{tabular}

Table 5. Distribution of Participants According to Their General Examination Positive Findings

Among the 50 Patients with acute pancreatitis, it was found that $56 \%$ were febrile, $40 \%$ patients were having raised respiratory rate, $36 \%$ were having pallor whereas $24 \%$ cases presented with icterus in local examination, $76 \%$ cases had tenderness. It was found that $32 \%$ cases presented with hypertension rest all had blood pressure within normal range. (Table 5 ).

\begin{tabular}{|c|c|c|c|}
\hline $\begin{array}{c}\text { Blood } \\
\text { Investigations }\end{array}$ & Parameter & $\begin{array}{c}\text { Number of } \\
\text { Participants }\end{array}$ & Percentage \\
\hline \multirow{2}{*}{ Haemoglobin } & $<10$ & 12 & $24 \%$ \\
\hline & $>10$ & 38 & $76 \%$ \\
\hline \multirow{2}{*}{$\begin{array}{c}\text { Total Leucocyte } \\
\text { Counts }\end{array}$} & $<12000$ & 10 & $20 \%$ \\
\hline & $>12000$ & 40 & $80 \%$ \\
\hline \multirow{2}{*}{ BSR } & $<200$ & 32 & $64 \%$ \\
\hline & $>200$ & 18 & $36 \%$ \\
\hline \multirow{2}{*}{ Serum Bilirubin } & $<1.5 \mathrm{mg}$ & 8 & $16 \%$ \\
\hline & $>1.5 \mathrm{mg}$ & 42 & $84 \%$ \\
\hline \multirow{2}{*}{ Serum Lipase } & Low & 11 & $22 \%$ \\
\hline & Raised & 39 & $88 \%$ \\
\hline
\end{tabular}

In present study, it was found that 12 cases presented with haemoglobin less than $10 \mathrm{mg} / \mathrm{dl}$ (Anaemia), In 40 cases raised TLC was observed (More than 12000), same cases presented with fever. Rest of the cases were having TLC less than 12000. Random blood sugar estimation was done among the cases of acute pancreatitis, it was found that 18 cases were having BSR more than $200 \mathrm{mg} / \mathrm{dl}$. Serum bilirubin estimation was also done, 42 cases were found with serum bilirubin more than $1.5 \mathrm{mg}$. Serum lipase values were found to be elevated in majority of cases (39), which is considered to be suggestive of pancreatitis (Table 6)

\section{DISCUSSION}

The present study was conducted to study the clinical presentation of acute pancreatitis among the suspected cases 
admitted to department of general medicine in tertiary case institute.

\section{Demography}

Out of 32 study participants, $88 \%$ were males and $22 \%$ were females (Table 2). Here we observed that male participants outnumbered the female participants. Crisanto BA et al, ${ }^{[4]}$ in their study enrolled 23 males and 15 female cases (47). Similar findings were notes by Khaled YS et al[5] reports 28 male and 12 female subjects in their study(50). However, Simo KA et al[6], they found more female study participants (10 out of 15 subjects) (49) and Hauters $P$ et al[7] also reported 5 male and 7 females among their study participants (46).

\section{Age Incidence}

Out of 32 study participants, $88 \%$ were males and $22 \%$ were females. Here we observed that male participants outnumbered the female participants Crisanto BA et al[4], in their study found mean age of participants as 38.8 years (47). Khaled YS et al[5] reports 55 years as a mean age of study subjects (50). Hauters $P$ et al[7] observes that the median age of 46 years (range: 30-72) (46). Similarly study by Simo KA et al[6] reports the median age of the cohort was $49.5 \pm 12$ years (range $=18-71)$ (49).

\section{Personal History}

In this study it was observed that $54 \%$ patients had a history of chronic alcoholism, $24 \%$ patients had history of smoking. It was found that $70 \%$ of study participants were having mixed pattern of diet, while $1030 \%$ study participants were having strict vegetarian pattern of diet. Crisanto BA et al,[4] in their study found that $29 \%$ cases gave history of alcoholism (47). Park et al found history of alcoholism in $18.5 \%$ cases, while Hamza et al, ${ }^{[8]}$ Mori et al ${ }^{[9]}$ and Hauters $\mathrm{P}$ et al[7] found that $30 \%$ cases had history of alcoholism (52)(46)(54).

\section{Clinical Presentation of Pancreatic Pseudocyst}

The clinical presentation of cases of acute pancreatitis observed as per the present study was as given in Table 5. Almost all patients (96\%) with PP presented with abdominal pain and lump in abdomen (92\%). 62\% had complaints of fever, $46 \%$ presented with nausea and vomiting. $40 \%$ cases complained of weight loss. BA Crisanto-Campos et al[4] in their study reported that out of 17 cases, 15 complained of epigastric pain, 6 cases reported with early satiety, 3 cases reported with weight loss and 2 cases reported with infected pancreatic pseudocyst (47).

\section{General Findings}

Among the 50 Patients with acute pancreatitis, it was found that $56 \%$ were febrile, $40 \%$ patients were having raised respiratory rate, $36 \%$ were having pallor whereas $24 \%$ cases presented with icterus In local examination, $76 \%$ cases had tenderness. It was found that $32 \%$ cases presented with hypertension rest all had blood pressure within normal range.

\section{Investigations Findings}

In present study, it was found that 12 cases presented with haemoglobin less than $10 \mathrm{mg} / \mathrm{dl}$ (Anaemia), In 40 cases raised TLC was observed (More than 12000), same cases presented with fever. Rest of the cases were having TLC less than 12000. Random blood sugar estimation was done among the cases of acute pancreatitis, it was found that 18 cases were having BSR more than $200 \mathrm{mg} / \mathrm{dl}$. Serum bilirubin estimation was also done, 42 cases were found with serum bilirubin more than $1.5 \mathrm{mg}$. Serum lipase values were found to be elevated in majority of cases (39), which is considered to be suggestive of pancreatitis.

\section{CONCLUSIONS}

Early assessment of severity and intensive care management of acute pancreatitis is of paramount importance. Lab markers especially high values of lipase and other markers could be important prognostic markers for predicting morbidity and mortality in acute pancreatitis.

\section{REFERENCES}

[1] Gurusamy KS, Pallari E, Hawkins N, et al. Management strategies for pancreatic pseudocysts. Cochrane Database Syst Rev 2016;2016(4):CD011392. http://as.wiley.com/WileyCDA/Brand/id-

6.html\%5Cnhttp://ovidsp.ovid.com/ovidweb.cgi?T=JS $\& P A G E=$ reference $\& D=$ emed $14 \& N E W S=N \& A N=20160$ 302242

[2] Cannon JW, Callery MP, Vollmer CM Jr. Diagnosis and management of pancreatic pseudocysts: what is the evidence? J Am Coll Surg 2009;209(3):385-93.

[3] Bradley EL 3rd. A clinically based classification system for acute pancreatitis: summary of the International Symposium on Acute Pancreatitis, Atlanta, Ga, September 11 through 13, 1992. Arch Surg 1993;128(5):586-90.

[4] Crisanto-Campos BA, Arce-Liévano E, CárdenasLailson LE, et al. Laparoscopic management of pancreatic pseudocysts: experience at a general hospital in Mexico City. Rev Gastroenterol Mex 2015;80(3):198-204.

[5] Khaled YS, Malde DJ, Packer J, et al. Laparoscopic versus open cystgastrostomy for pancreatic pseudocysts: a case-matched comparative study. J Hepatobiliary Pancreat Sci 2014;21(11):818-23.

[6] Simo KA, Niemeyer DJ, Swan RZ, et al. Laparoscopic transgastric endolumenal cystogastrostomy and pancreatic debridement. Surg Endosc 2014;28(5):1465-72.

[7] Hauters P, Weerts J, Peillon C, et al. Laparoscopic treatment of pancreatic pseudocysts. Surg Endosc Other Interv Tech 2017;18(11):1645-8.

[8] Hamza N, Ammori BJ. Laparoscopic drainage of pancreatic pseudocysts: a methodological approach. J Gastrointest Surg 2010;14(1):148-55.

[9] Mori T, Abe N, Sugiyama M, et al. Laparoscopic pancreatic cystgastrostomy. J Hepatobiliary Pancreat Surg 2000;7(1):28-34. 